A Multi-Sectoral Analysis of

Feed Grain Exports in the Cornbelt Economy

by

Thomas R. Smith, E. Dean Baldwin and Donald W. Larson

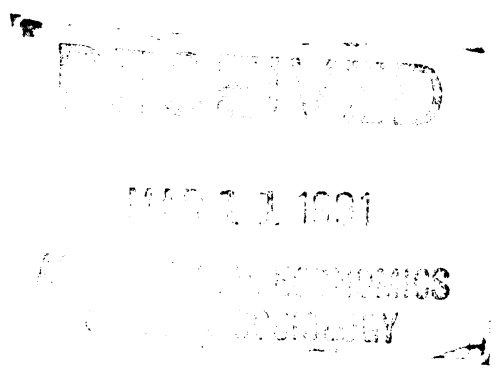


A Multi-Sectoral Analysis of

Feed Grain Exports in the Cornbelt Economy

By

Thomas R. Smith, E. Dean Baldwin and Donald W. Larson*

\begin{abstract}
Large feed grain export variations adversely impact the agricultural sector and the Cornbelt economy. A multi-sectoral input-output linear programming model is developed to measure the cross industry effects of a ten percent increase in feed grain exports. Base model, elastic labor supply, and full employment labor supply results are presented.
\end{abstract}

*Post Doctoral Fellow, Associate Professor and Professor, respectively, Department of Agricultural Economics and Rural Sociology, The Ohio State University, Columbus, Ohio 


\section{A Multi-Sectoral Analysis of Feed Grain Exports in the Cornbelt Economy}

\section{Introduction}

International trade policy requires making inter-sectoral comparisons and dictates sector-by-sector trade-offs in terms of income and employment while maximizing national output and maintaining full employment. Increases or decreases in U.S. feed grain exports (corn, sorghum and oats) affect business activities of grain farmers, merchandisers and grain processors, and influence the Cornbelt economy as a whole. Determining these trade-offs for different trade policies is of interest to farmers, business people, policy makers and economic planners (Pagoulatos, Pagoulatos, and Sorenson, and Harrington, Schluter, and $\left.0^{\prime} B r i a n\right)$. These researchers have examined the effects of different trade policies from a regional multi-sectoral perspective, or from a single feed grain sector viewpoint.

The input-output model has been used in the regional analysis to measure cross-industrial linkages; these models assume an infinite supply of regional inputs and a perfectly mobile labor supply. Feed grain industry studies employing linear programming models (Hoffman, Hill, and Leath, Baldwin and Larson, and Koo) have shown that changes in feed grain export volume cause significant changes within the feed grain industry regarding grain production, merchandising, transportation and storage patterns. However, these feed grain industry models do not measure cross-industry income and employment effects relative to other industrial sectors found in a given regional economy. The methodological gap between regional analysis employing the input-output model and the feed grain sector analysis using linear programming models is 
bridged in this study by employing input-output technical coefficients as linear programming constraints, by adding a labor supply constraint and by creating shadow prices through ranging the right-hand-side coefficients or constraints.

The objective of this paper is to measure Cornbelt (Ohio, Indiana, Illinois, Iowa and Missouri) cross-industry linkages, and the effect of a ten percent increase in feed grain exports on the Cornbelt economy which is assumed to have a perfectly elastic supply of mobile labor resources in the first case and is at full employment in the second case. At full employment, expansion of feed grain exports would likely create labor shortages in other sectors of the cornbelt economy. Shadow prices are derived to determine the amount of expenditure that could be made by Cornbelt policy makers per additional dollar of exports to increase employment or to retrain workers (subsidize export expansion). A thirteen sector input-output model of the Cornbelt economy is solved for industry outputs, and serves as a base model against which to compare the two scenarios.

\section{$\underline{\text { Data }}$}

\section{Data and Model Specification}

Data for this research were acquired from several sources: the ADOTMATR software package purchased from Resource Economics and Management Analysis, Inc., Cornbelt grain flow data from North Central and Southern Regional Committee publications for the year 1977, and Commerce

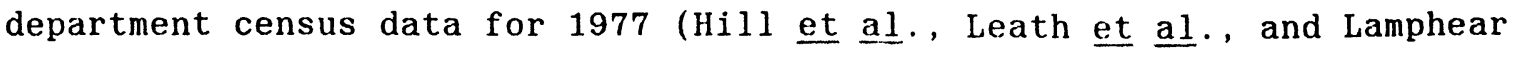
and Konecny). The software package ADOTMATR contained the 1977 U.S. Input-Output model created by the Commerce department. This 537 sector 
model operates on an IBM compatible micro computer. The aggregated U.S. data presented by the software was regionalized using national 1977 census data for all input-output industry classifications at the two digit level with the exception of the feed grain sector which was left disaggregated (Ritz). The simple location quotient technique was employed to regionalize the model as described in Miller and Blair. The regionalized model resulted in a 13 sector input-output model (Households endogenous, Type II Model) that represented all economic activity within the Cornbelt (Table 1). Census data from 1977 revealed the employment and sales revenues for each industry ( $\$ 11$ billion for the grain sector, for example, Table 2). The ratio of sector employment to sector sales revenues is presented in Table 3 .

Base model output results are calibrated to match the comparative census data that are used in the study. A vector of total outputs was found by multiplying the inverted (I-A) matrix (Household endogenous) by the vector of exogenous final demands. For the base model, this vector (13 $\times 1$ ) was derived by using census total sales by Input-Output Industrial Classification category and then adjusting the model for negative final demands (Ritz). Final demands are the exports from the Cornbelt to either non-Cornbelt states in the U.S. or to foreign countries. Total final demand for the Cornbelt region was $\$ 230$ billion (Table 2). The households sector generated the largest final demand, $\$ 103$ billion. Manufacturing was next, with over $\$ 80$ billion. Final demands for the livestock, other agriculture, feed grain and construction sectors ranged from $\$ 763$ million to $\$ 31$ billion. The seven 
industries with a zero final demand (exports) indicate that the Cornbelt is a net importer of the given commodity or service (Table 2). Multiplying the total requirements matrix by the final demand vector yields a $13 \times 1$ matrix of total outputs, the output for each sector that satisfies known intermediate demands, final demands, and sales revenues. For 1977, the sum of total outputs, or Total Cornbelt Output was $\$ 798$ billion, and $\$ 11$ billion for the grain sector, for example (Table 2).

The model requires an exogenous determination of the level of feed grain exports to foreign countries from the Cornbelt. Total demand (both for export and domestic use) of corn, oats, and sorghum was 3.1 billion bushels in $1977,1.4$ billion of which stayed in the Cornbelt for intermediate demands (Table 4 ). The remaining 1.7 billion bushels satisfied final demands. Of the 1.7 billion bushels of final demand, 131 million were exported to foreign countries directly from the Cornbelt and 1.2 billion bushels were exported to foreign countries via the rest of the U.S. The remaining 359 million bushels satisfied the rest of the U.S. intermediate demands. Aggregate exports to foregin countries from the Cornbelt thus totaled 1.4 billion bushels in 1977 , nearly 80 percent of Cornbelt final demand for feed grains.

\section{Model Specification}

The input-output/linear programming model can be specified in a linear programming format in which prices are treated as exogenous (Penn

et al.). Total output or gross sales for the Cornbelt region is maximized (Equation 1). The first thirteen constraints represent interindustry constraints or cross purchasing requirements of the Cornbelt 
industries as found in the input-output model of the Cornbelt (Equation 2). The fourteenth constraint models labor usage and total labor availability within the Cornbelt (Equation 3). Employment coefficients were derived from census data and total industrial output for each sector as discovered in the input-output model of the Cornbelt. Coefficients of this row equal the number of employees per dollar of industry output (Equation 3). The EMPL element equals the total number of employees found in the Cornbelt region as listed in the 1977 census. The matrix $X$ is the column vector of unknown industrial outputs for which one must solve.

(1) Maximize PX s.t.

$$
\begin{aligned}
(\mathrm{I}-\mathrm{A}) \mathrm{X} & \leq \mathrm{FD} \\
\mathrm{EX} & \leq \mathrm{EMPL}
\end{aligned}
$$

where:

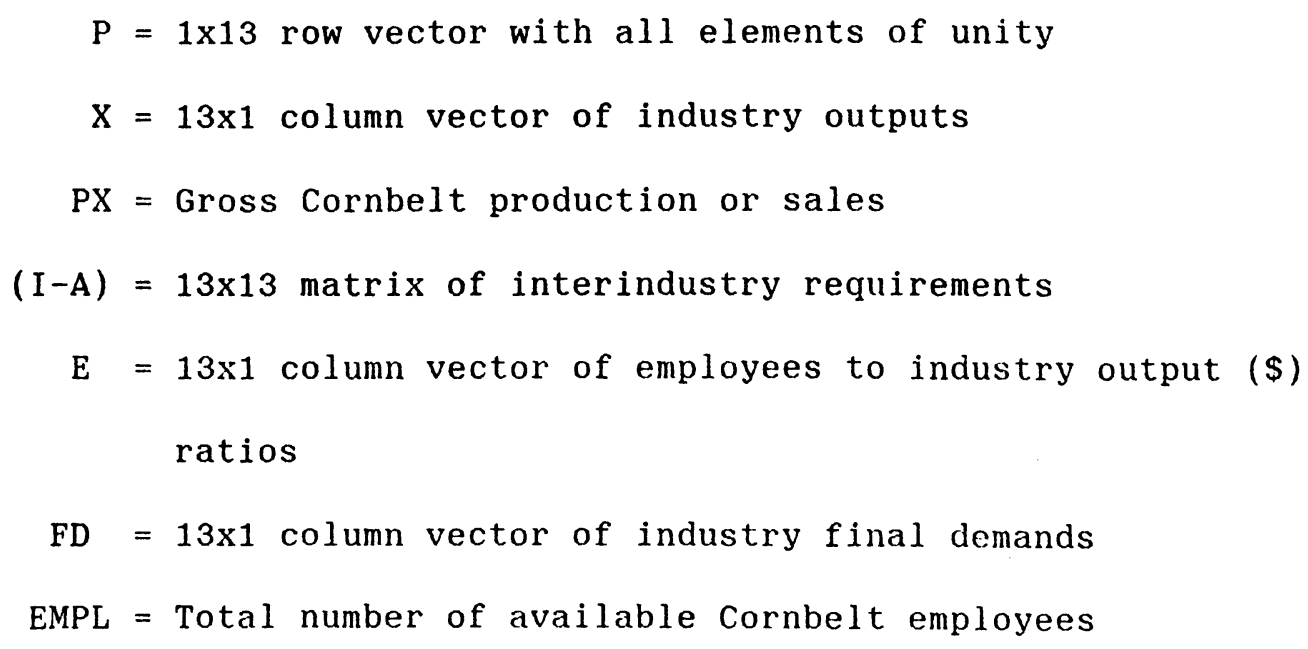

The model is solved for three alternatives. The base model simulates the comparative 1977 census data that are used in the study. The second alternative simulates a 10 percent increase in feed grain 
exports (the relative increase from 1977 to 1979) without a labor constraint. The third alternative simulates a 10 percent increase in feed grain exports with a labor constraint. The labor supply was constrained at the 1977 level because the Cornbelt economy was generally considered to be at full employment in that period. In the late 1970s, the unemployment rate of the Cornbelt was less than that of the U.S. as a whole, indicating a labor shortage in this region relative to the U.S. (U.S. Statistical Abstract).

\section{Base Model}

Results

Base model coefficients indicate the degree to which the feed grain sector is important to the entire Cornbelt economy. Individual elements of the linear program constraint coefficients matrix, $A$, measure the amount of an additional dollar spent on a purchase of the ith sector's good. This element represents the direct economic linkage between the jth and ith sector. For example, feed grains (column 3 ) and manufacturing (row 8) are strongly linked (Table 5). For every dollar spent by the feed grain sector, 22.7 cents is spent on manufacturing goods produced in the Cornbelt. Since feed grain production is known to be capital intensive, this finding is consistent with expected results. The feed grain sector has a weak backward linkage to the food manufacturing industry. For each dollar spent by the feed grain industry, only 0.01 cents is spent purchasing goods from food manufacturers. The feed grain industry spends over 7 percent of its revenues purchasing financial services (row 11, column 3 , Table 5 ). This relationship is also consistent with the fact that the feed grain industry is heavily 
dependent on financial services to perform the production, storage and merchandising functions.

Summing the first thirteen constraints for each column yields the value added for each dollar of output by the given sector in the Cornbelt. The feed grain industry spends approximately 50 percent of its revenue in the value added category, which includes returns on investments and interest. of the intermediate industries delineated in this study, only three (other agriculture, mining and finance) have value added coefficients greater than that of the feed grain industry. The feed grain industry has a relatively high value added coefficient because it is a capital intensive industry and most production and merchandising functions are debt financed.

Simulation of a Ten Percent Increase In Feed Grain Exports Without the 1977 Labor Constraint

The unconstrained estimation of outputs given a ten percent increase in feed grain demand is given in Table 6. The right hand side or the feed grain final demand was set equal to $\$ 6.57$ billion for this alternative (Smith). The results indicate that Cornbelt total output is increased by 0.16 percent, over 1.2 billion dollars (Table 6 ). The agriculturally oriented sectors ( 1 through 4 ) are the most affected. Of course, the feed grain sector increases output the most, rising by 4.65 percent from the base model output of $\$ 11$ billion, as production increases by $\$ 513$ million. The livestock sector increases by $\$ 22$ million, the dairy sector by $\$ 3.4 \mathrm{million}$ and other agriculture by $\$ 6.9$ million.

of the non-agricultural sectors in the Cornbelt, output in the finance sector increased the most, experiencing a rise of 0.17 percent 
or $\$ 72$ million. The transportation sector had to expand services by 0.13 percent or $\$ 40.4$ million dollars. Manufacturing increased by $\$ 265$ million, a 0.10 percent increase. The least affected sectors were construction and households, increasing by only 0.03 and 0.07 percent, respectively, from their base output levels.

Employment increases in the Cornbelt by over 25,000 jobs when feed grain exports increase by 10 percent and labor is unconstrained (Table 7). Over 40 percent of those jobs are generated in the feed grain sector and another 40 percent in the manufacturing, wholesale/retail, and service sectors combined. The feed grain sector would create 10,997 jobs while the manufacturing sector would create 3,717 jobs.

Simulation of a Ten Percent Increase in Feed Grain Exports with the 1977 Labor Constraint

Total Cornbelt output for the constrained labor simulation was less than one-tenth of one percent above that of the base model or an increase of $\$ 639$ million (Table 6 ). This is about one-half the increase that was observed for the unconstrained labor simulation with a 10 percent increase in exports.

Employment does not increase by 25,102 jobs when labor is constrained to equal the base model amount (Table 7). Instead, employees are shifted out of the wholesale/retail sector and into other sectors of the Cornbelt economy. The wholesale/retail sector loses 15,845 employees to other sectors in the economy. The food manufacturing sector creates 72 percent fewer jobs when an increase in feed grain exports is coupled with a labor shortage situation. 
As with other simulations, the sectors experiencing the largest percentage increases in output were feed grains, livestock, other agriculture and dairy. When labor was constrained, the dairy sector output increased by only 0.20 percent. In other words, a growth of 0.05 percent was denied the Cornbelt dairy sector due to labor constraints. The feed grain sector was among the least of the agricultural sectors affected by the labor constraint, because of the direct effects of the increase in export demand. Wholesale/retail trade, finance, and service and other were the most affected sectors. Labor constraints caused the finance and service sectors to grow by less than half the rate they would have without labor constraints.

The wholesale/retail sector was the most negatively affected. Output from that sector actually declined nearly seven tenths of one percent due to a labor shortage. This decline amounted to a decrease in output of $\$ 189$ million for the wholesale/retail trade sector (Table 6). For the wholesale/retail sector, decreased outputs result in final demand not being met. Final demand is zero for this sector, thus the sector would import goods from non-Cornbelt regions to cover its production shortage. The shortfall amounts to $\$ 263$ million and is identified as a slack activity in the linear programing solution. The cost of importing these goods is not incorporated in the model.

Labor resources would be reallocated from those sectors experiencing declines in sales to sectors with increased outputs, such as the feed grain sector. The benefit to the Cornbelt of facilitating the labor adjustment process can be measured by the increase in total Cornbelt output from the increased foreign export demand. The increase in output 
(the difference between the constrained and unconstrained labor simulations) is nearly $\$ 615$ million (Table 6).

\section{Shadow Values}

Shadow values are used to trace marginal revenue product curves as well as supply curves for the Cornbelt feed grain sector. As long as all economic sectors are in the solution as basic variables, i.e., as long as they meet their final demands, the shadow values are unchanged. In these cases, marginal revenue product does not decline but instead remains constant. This condition occurs when the employment constraint is inactive. Holding all other final demands constant and increasing feed grain final demands by enough to change the basis, one can obtain ever decreasing shadow values (Table 8 ).

The labor constrained simulation can be expanded and the shadow values of the feed grain sector recorded as the marginal revenue gained by the Cornbelt if feed grain exports are expanded. Shadow price values represent the Cornbelt's upper limit of spending per extra dollar of exports. The value added portion of the shadow price is the amount the Cornbelt would be willing to pay to gain one dollar's worth of new exports. To spend more than this amount would cause total regional output to increase by less than the cost of obtaining the opportunity to expand feed grain exports.

In the base model, the shadow value for an additional dollar of feed grain exports is $\$ 2.58$ when non Cornbelt demand including exports is constrained at $\$ 6.09$ billion (Table 8 ). When feed grain final demand is at $\$ 6.57$ billion for the Cornbelt, additional exports of $\$ 1$ will cause total Cornbelt revenue to increase by only $\$ 1.31$. The average 
value added portion of output in the Cornbelt is 29 percent, as calculated from the transactions table (Smith). Thus, the Cornbelt would break even if the cost of increasing its exports by $\$ 1$ was $\$ 0.38(\$ 1.31$. $x 0.29$ ). Feed grain exports could increase to $\$ 97$ billion (a sixteenfold increase) before the break even cost dropped to $\$ 0.24(\$ 0.84$. $x$ 0.29). Expanding feed grain exports becomes a non-revenue increasing effort when the shadow value equals zero. When feed grain exports from the Cornbelt equal $\$ 248.8$ billion, a marginal increase in exports results in no increase in Cornbelt revenue (Table 8 ).

Any increase in feed grain production or export causes resources of the Cornbelt to be shifted to the feed grain sector and away from other sectors. The most labor intensive sector in this case is the wholesale/ retail trade sector. When the model is constrained by employment and forced to accept a ten percent increase in foreign export demand for feed grains (an increase of $\$ 6.09$ billion to $\$ 6.57$ billion in feed grain final demands), the wholesale/retail trade sector decreases sales by $\$ 190$ million while the Cornbelt gains $\$ 640$ million (Table 9). To measure the marginal revenue product of an increase in feed grain output, feed grain final demand is increased even further to $\$ 97.4$ billion. As a result, wholesale/retail trade decreases sales by $\$ 35.6$ billion and shuts down while the Cornbelt gains $\$ 119$ billion in total sales (Table 9). Theoretically, the cost of a subsidy given to the feed grain sector to promote feed grain exports should include losses experienced by the wholesale/retail sector. In short, if subsidies given to the feed grain sector and compensation given to the wholesale/retail sector amounted to less than $\$ 0.38(\$ 1.31 \times 0.29)$ per dollar increase in 
feed grain exports, then the Cornbelt would increase total net output by subsidizing feed grain exports.

\section{Conclusions and Implications}

International trade policy negotiations require an assessment of the costs and benefits, in terms of income and employment to the Cornbelt and to individual industries within the Cornbelt, of allowing foreign tariffs or quota levels upon U.S. feed grains to change. A ten percent increase in the quantity of feed grain exports results in a 0.16 percent increase in Cornbelt sales, over $\$ 1.2$ billion. Agricultural sectors increase their sales by $\$ 546.4$ million while manufacturing sectors increase their sales by $\$ 295$ million. At the other extreme, if feed grain exports decrease by 10 percent from the Cornbelt, this will cause Cornbelt sales to decrease by a proportional amount.

These findings also imply that public planners and policy makers should determine the extent to which monetary and export policies affect the Cornbelt industries. Tight monetary policies and deficit fiscal policies are believed to dampen exports such as feed grains. Knowing the direction and magnitude of policy impacts, parallel plans or policies can be applied to ease resource transition between sectors. Parallel policies might include job retraining programs, export enhancement programs, or production subsidy programs.

This study estimates the upper limit for the Cornbelt to subsidize a 10 percent increase in the export of feed grains to be $\$ 609$ million since the estimated benefit from a 10 percent increase in feed grain exports is $\$ 609 \mathrm{million}$ of value added. The federal Target Export Assistance program had a budget of $\$ 110 \mathrm{million}$ to promote exports of 
corn, sorghum, and barley for 1987 (Pollack). To be cost effective, this program must generate at least $\$ 110$ million of value added benefits for the U.S. This study found that a one percent increase in feed grain exports benefits the Cornbelt by $\$ 61$ million. Thus, feed grain exports must increase by at least 1.8 percent $(\$ 110 \mathrm{million} / \$ 61 \mathrm{million})$ in order for the program to be cost effective. Since the cornbelt did not financially support 100 percent of the Target Export Assistance program, the Cornbelt need not attain a full 1.8 percent increase in feed grain exports. The rest of the U.S. benefits as well. Retaliatory measures taken by other grain exporting nations have not been included in calculating the costs of this export subsidy.

A second parallel policy that might be considered to ease resource transition deals with employment and labor availability. From a costbenefit viewpoint, the benefits to all of the Cornbelt of increased exports of feed grains can be measured in terms of sales revenue increases and employment opportunity increases. These benefits are possible only if adequate numbers of trained employees exist in each sector. In the late 1970 s, the unemployment rate of the Cornbelt was less than that of the U.S. as a whole, indicating labor shortage in this region relative to the U.S. As a region, the Cornbelt should be willing to subsidize employee training or job searches (for faster placement) if the cost is less than the estimated benefits. The results of this paper estimate which sectors will experience large changes in employment and to what extent society could benefit from a larger pool of trained employees or a shorter period of frictional unemployment. The Cornbelt agricultural sectors were estimated to forego sales of $\$ 9$ billion when 
labor availability was not permitted to increase along with feed grain export demand. One concludes that to benefit most from an export subsidy offered to one sector, the feed grain sector in this case, a regionally coherent employment and training policy would be needed to insure that other sectors can meet new intermediate demands. On the one-hand, if labor is mobile these results overstate the cost to society of having an immobile or undertrained labor force. On the other hand, if labor costs increase relative to total outputs, these results understate the cost to society. 
Table 1. Base Model Aggregation of U.S. Industrial Sectors for Cornbelt Study, 1977

$\begin{array}{ll}\text { Industrial Category } & \text { I-0 Industrial } \\ \text { Classification }\end{array}$

1. Dairy Farm Products

10100

2. Other Livestock

$10200-10302$

3. Feed Grain

$20201-20202$

4. Other Agriculture

20100

$20203-20702$

$30001-40002$

5. Mining

$50000-100000$

6. Construction

$110101-120216$

7. Food Manufacturing

$140101-143200$

8. Manufacturing

$130100-130700$

$150101-641200$

9. Transportation

$650100-680302$

10. Wholesale/Retail Trade

$690100-690200$

11. Finance

$700100-710200$

12. Service

$720100-850000$

13. Household

880000

Sources: 1) Lamphear and Konecny

2) Ritz, Phillip M. "Definitions and Conventions of the 1972 Input - Output Study" Bureau of Economic Analysis Staff

Paper. July 1980. BEASP 80-034 
Table 2. Industry Sales Revenues and Final Demand, Cornbelt, 1977

\begin{tabular}{|c|c|c|c|c|}
\hline & \multirow[t]{2}{*}{ Sector } & Revenues & \multicolumn{2}{|c|}{ Final Demand } \\
\hline & & --1 & $.000)$ & -- \\
\hline 1. & Dairy Farm Products & 1,346 & & 0 \\
\hline 2 . & Livestock & 10,393 & & 763 \\
\hline 3. & Feed Grain & 11,040 & & 6,085 \\
\hline 4. & Other Agriculture & 2,304 & & 0 \\
\hline 5 . & Mining & 4,441 & & 0 \\
\hline 6 . & Construction & 37,649 & & 31,727 \\
\hline 7. & Food Manufacturing & 43,958 & & 6,798 \\
\hline 8. & Manufacturing & 253,208 & & 80,742 \\
\hline 9. & Transportation & 29,965 & & 0 \\
\hline 10 . & Whole/Retail Trade & 35,584 & & 0 \\
\hline 11. & Finance & 42,712 & & 0 \\
\hline 12. & Service and other & 64,219 & & 0 \\
\hline 13. & Household & 261,873 & & 103,954 \\
\hline & Total Cornbelt Output & 798,691 & & 230,071 \\
\hline
\end{tabular}

Source: Lamphear and Konecny 
Table 3. Employment Constraint Coefficients, Cornbelt, 1977

\begin{tabular}{cll}
\hline & Sector & $\begin{array}{c}\text { Employees Per Thousand } \\
\text { Dollars of Sales Revenue }\end{array}$ \\
1. & Dairy Farm Products & 0.0173 \\
2. & Livestock & 0.0234 \\
3. & Feed Grain & 0.0214 \\
4. & Other Agriculture & 0.0354 \\
5. & Mining & 0.0164 \\
6. & Construction & 0.0169 \\
7. & Manufacturing-Food & 0.0064 \\
8. & Manufacturing & 0.0140 \\
9. & Transportation & 0.0220 \\
10. & Whole/Retail Trade & 0.0835 \\
11. & Finance, Banking & 0.0167 \\
12. & Service and other & 0.0549 \\
13. & Household & 0.0011 \\
& & \\
\hline
\end{tabular}

Source: Lamphear and Konecny 
Table 4. Disappearance of Cornbelt Feed Grains, 1977

\begin{tabular}{lcc}
\hline & \multicolumn{2}{c}{ Million bushels } \\
\hline Cornbelt Intermediate Demand & 1,359 \\
Cornbelt Final Demand & 131 \\
$-\quad$ Exports from Cornbelt & 1,255 & \\
- Rest of U.S. Export Demand & 359 & 1,745 \\
- Rest of U.S. Intermediate Demand & & 3,104 \\
Subtotal Cornbelt Final Demands & & \\
Total Demand &
\end{tabular}

Source: Hill et al. 
Table 5. Linear Program Model Constraint Specifications for the 1977 Cornbelt Economy: Employment Constraint Included and a Ten Percent Increase in Feed Grain Exports Included

\begin{tabular}{|c|c|c|c|c|c|}
\hline & 1 & 2 & 3 & 4 & 5 \\
\hline Row* & Dairy & $\begin{array}{l}\text { Live- } \\
\text { Stock }\end{array}$ & $\begin{array}{l}\text { Feed } \\
\text { Grain }\end{array}$ & $\begin{array}{c}\text { Other } \\
\text { Agr. }\end{array}$ & Mining \\
\hline 1 & 0.9987 & -0.0031 & -0.0048 & -0.0003 & 0 \\
\hline 2 & -0.0011 & 0.7793 & -0.0241 & -0.0112 & 0 \\
\hline 3 & -0.3418 & -0.2386 & 0.9621 & -0.0007 & 0 \\
\hline 4 & -0.0071 & -0.0125 & -0.0094 & 0.9766 & 0 \\
\hline 5 & -0.0001 & -0.0001 & -0.0012 & -0.0003 & 0.9821 \\
\hline 6 & -0.0068 & -0.0049 & -0.0101 & -0.0129 & -0.0323 \\
\hline 7 & -0.2103 & -0.2101 & -0.0001 & -0.0026 & -0.0001 \\
\hline 8 & -0.0295 & -0.0364 & -0.2268 & -0.1303 & -0.0943 \\
\hline 9 & -0.0239 & -0.0167 & -0.0269 & -0.0162 & -0.0215 \\
\hline 10 & -0.0165 & -0.0233 & -0.0294 & -0.0216 & -0.0085 \\
\hline 11 & -0.0245 & -0.0233 & -0.0738 & -0.0426 & -0.0453 \\
\hline 12 & -0.0084 & -0.0126 & -0.0174 & -0.0191 & -0.0234 \\
\hline 13 & -0.0566 & -0.0559 & -0.036 & -0.1452 & -0.1526 \\
\hline 14 & 0.0173 & 0.0234 & 0.0214 & 0.0354 & 0.0164 \\
\hline
\end{tabular}

\begin{tabular}{|c|c|c|c|c|c|c|}
\hline & 6 & 7 & 8 & 9 & 10 & \\
\hline Row* & $\begin{array}{l}\text { Const- } \\
\text { ruction }\end{array}$ & $\begin{array}{l}\text { Food } \\
\text { Mftg. }\end{array}$ & Mftg. & $\begin{array}{c}\text { Trans- } \\
\text { port }\end{array}$ & $\begin{array}{l}\text { Whole/ } \\
\text { Ret.Tr }\end{array}$ & \\
\hline
\end{tabular}

\begin{tabular}{rrlrrr}
\hline 1 & 0 & -0.0245 & 0 & 0 & 0 \\
2 & 0 & -0.143 & -0.0002 & 0 & 0 \\
3 & 0 & -0.0305 & -0.0001 & 0 & 0 \\
4 & -0.0008 & -0.0183 & -0.002 & 0 & -0.0005 \\
5 & -0.0023 & -0.0003 & -0.0142 & -0.0167 & -0.0001 \\
6 & 0.999 & -0.0039 & -0.0049 & -0.0303 & -0.0057 \\
7 & -0.0002 & 0.8282 & -0.0017 & -0.0003 & -0.0008 \\
8 & -0.3739 & -0.1163 & 0.6626 & -0.0963 & -0.0412 \\
9 & -0.0197 & -0.0241 & -0.0262 & 0.9013 & -0.0346 \\
10 & -0.0482 & -0.0296 & -0.0188 & -0.0074 & 0.9929 \\
11 & -0.0069 & -0.0045 & -0.0067 & -0.013 & -0.0332 \\
12 & -0.0431 & -0.0384 & -0.0283 & -0.0456 & -0.0802 \\
13 & -0.3182 & -0.1248 & -0.3377 & -0.2626 & -0.3922 \\
14 & 0.0169 & 0.0064 & 0.0140 & 0.0220 & 0.0835 \\
\hline
\end{tabular}

* Row numbers correspond to column headings. Row number 14 is the employment constraint. 
Table 5. Linear Program Model Constraint Specifications for the (cont'd) 1977 Cornbelt Economy: Employment Constraint Included and a Ten Percent Increase in Feed Grain Exports Included

\begin{tabular}{|c|c|c|c|c|}
\hline & 11 & 12 & 13 & RHS \\
\hline Row* & $\begin{array}{l}\text { Fin- } \\
\text { ance }\end{array}$ & $\begin{array}{c}\text { Serv \& } \\
\text { Other }\end{array}$ & $\begin{array}{l}\text { House- } \\
\text { holds }\end{array}$ & $\begin{array}{l}\text { Final } \\
\text { Demand }\end{array}$ \\
\hline
\end{tabular}

(000\$)

$\begin{array}{rrrrllr}1 & 0 & -0.0003 & -0.0006 & \leq & 0 \\ 2 & 0 & -0.0013 & -0.0023 & \leq & 763,380 \\ 3 & 0 & -0.0018 & -0.0005 & \leq & 6,572,027 \\ 4 & -0.0011 & -0.001 & -0.0021 & \leq & 0 \\ 5 & 0 & -0.0007 & -0.0004 & \leq & 0 \\ 6 & -0.0431 & -0.0181 & 0 & \leq & 31,727,280 \\ 7 & 0 & -0.0515 & -0.0891 & \leq & 6,798,380 \\ 8 & -0.0135 & -0.0936 & -0.2034 & \leq & 80,742,240 \\ 9 & -0.0125 & -0.0345 & -0.0533 & \leq & 0 \\ 10 & -0.0015 & -0.0154 & -0.0974 & \leq & 0 \\ 11 & 0.9188 & -0.0294 & -0.1231 & \leq & 0 \\ 12 & -0.0345 & 0.9355 & -0.1658 & \leq & 0 \\ 13 & -0.1364 & -0.3928 & 1 & \leq & 103,954,400 \\ 14 & 0.0167 & 0.0549 & 0.0011 & \leq & 13,258,750\end{array}$

* Row numbers correspond to column headings. Row number 14 is the employment constraint. 
Table 6. Comparison of Base Model Results, Unconstrained Labor Results, and Constrained Labor Results, Given a Ten Percent Export Increase Scenario

\begin{tabular}{|c|c|c|c|c|c|}
\hline \multirow{3}{*}{ Sector } & \multirow{3}{*}{$\begin{array}{l}\begin{array}{l}\text { Base } \\
\text { Model } \\
\text { Output }\end{array} \\
\$ 000\end{array}$} & \multicolumn{4}{|c|}{$\begin{array}{l}\text { Changes in Base Results Due to a } \\
10 \% \text { Increase in Feed Grain Exports }\end{array}$} \\
\hline & & \multicolumn{2}{|c|}{$\begin{array}{c}\text { Unconstrained } \\
\text { Results }\end{array}$} & \multicolumn{2}{|c|}{$\begin{array}{l}\text { Constrained Labor } \\
\text { Supply Results }\end{array}$} \\
\hline & & $\$ 000$ & Percent & $\$ 000$ & Percent \\
\hline Dairy & $1,346,105$ & 3,400 & 0.25 & 2,725 & 0.20 \\
\hline Livestock & $10,392,812$ & 22,257 & 0.21 & 17,574 & 0.17 \\
\hline Feed Grain & $11,039,683$ & 513,885 & 4.65 & 511,607 & 4.63 \\
\hline Other Agri. & $2,303,654$ & 6,926 & 0.30 & 5,720 & 0.25 \\
\hline Mining & $4,440,835$ & 5,331 & 0.12 & 3,588 & 0.08 \\
\hline Construction & $37,649,000$ & 12,741 & 0.03 & 7,706 & 0.02 \\
\hline Food Mftg. & $43,958,206$ & 30,291 & 0.07 & 8,480 & 0.02 \\
\hline Mftg. & $253,208,499$ & 265,510 & 0.10 & 183,569 & 0.07 \\
\hline Transportation & $29,964,866$ & 40,402 & 0.13 & 16,536 & 0.06 \\
\hline Whole/Retail & $35,584,224$ & 41,495 & 0.12 & $(189,759)^{a}$ & $(0.67)$ \\
\hline Finance & $42,711,716$ & 72,774 & 0.17 & 40,353 & 0.09 \\
\hline Service/other & $64,218,933$ & 60,108 & 0.09 & 6,627 & 0.01 \\
\hline Household & $261,872,689$ & 179,680 & 0.07 & 24,454 & 0.01 \\
\hline Total & $798,691,222$ & $1,254,790$ & 0.16 & 639,180 & 0.08 \\
\hline
\end{tabular}

a Parenthesis means decrease. 
Table 7. Change in Number of Employees, Relative to the Base Mode, Unconstrained Labor Results, and Constrained Labor Results, Given a Ten Percent Export Increase Scenario

\begin{tabular}{|c|c|c|c|}
\hline \multirow[b]{2}{*}{ Sector } & \multicolumn{3}{|c|}{ Feed Grain Export Increase of Ten Percent } \\
\hline & $\begin{array}{l}\text { With Unlimited } \\
\text { Labor } \\
\text { Availability }\end{array}$ & $\begin{array}{l}\text { With Labor Avail- } \\
\text { ability Limited to } \\
\text { Base Model Amount }\end{array}$ & $\begin{array}{l}\text { Percent } \\
\text { Difference }\end{array}$ \\
\hline & -- Number & of Jobs -- & Percent \\
\hline Dairy Farm Products & 59 & 47 & 20 \\
\hline Livestock & 521 & 411 & 21 \\
\hline Feed Grains & 10,997 & 10,948 & 0 \\
\hline Other Agriculture & 245 & 202 & 17 \\
\hline Mining & 87 & 59 & 33 \\
\hline Construction & 215 & 130 & 40 \\
\hline Food Manufacturing & 194 & 54 & 72 \\
\hline Manufacturing & 3,717 & 2,570 & 31 \\
\hline Transportation & 889 & 364 & 59 \\
\hline Whole/Retail Trade & 3,465 & $(15,845)^{\mathrm{a}}$ & $(557)^{a}$ \\
\hline Finance & 1,215 & 674 & 45 \\
\hline Service \& Other & 3,300 & 364 & 89 \\
\hline Household & 198 & 27 & 86 \\
\hline Total & 25,102 & $6 *$ & \\
\hline
\end{tabular}

* Not equal to zero due to rounding.

a Parentheses means decrease. 
Table 8. Shadow Values of Feed Grain Sector for the Base Model, an Inelastic Labor Supply Scenario, and Four "RHS" Upper Limit Scenarios

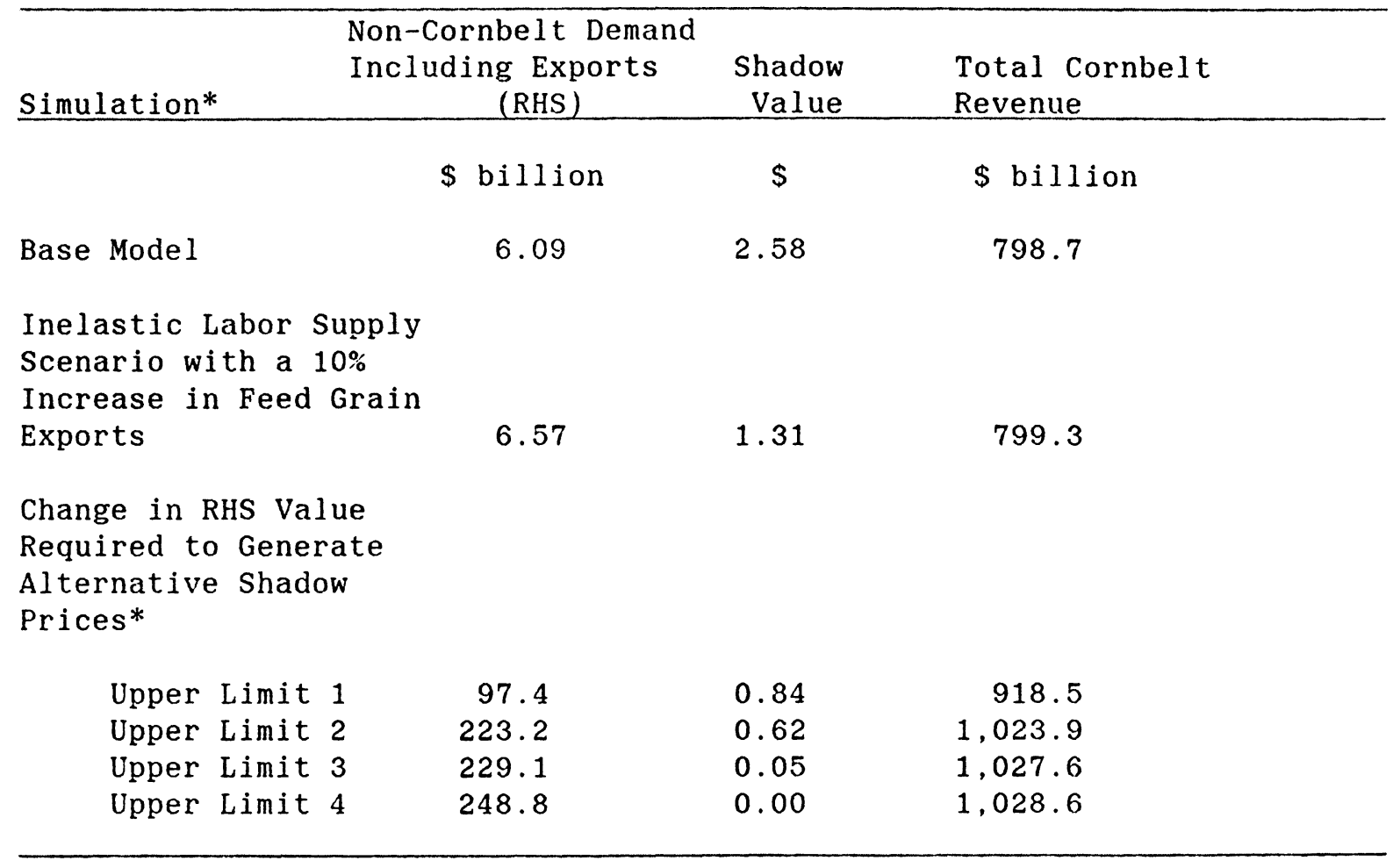

* For upper limit scenarios one through four, the upper limit of the previous simulation's Right Hand Side value for the feed grain sector is employed as the new RHS value in order to generate a new shadow price. 
Table 9. Effect of Increased Feed Grain Exports Upon the Wholesale/Retail Trade Sector

\begin{tabular}{|c|c|c|c|}
\hline $\begin{array}{l}\text { Change in } \\
\text { Feed Grain } \\
\text { Final Demands }\end{array}$ & $\begin{array}{l}\text { Gain to Feed } \\
\text { Grain Sector }\end{array}$ & $\begin{array}{l}\text { Gain to } \\
\text { Cornbelt }\end{array}$ & $\begin{array}{l}\text { Loss to } \\
\text { Wholesale/Retail }\end{array}$ \\
\hline & & $-\$ b i$ & -- \\
\hline 6.09 to 6.57 & 0.51 & 0.64 & 0.19 \\
\hline 6.09 to 97.40 & 91.86 & 119.24 & 35.58 \\
\hline
\end{tabular}




\section{References}

Baldwin, E. Dean and Donald W. Larson. "U.S. Grain Marketing Systems for the 1990's: Alternative Policy Scenarios." OARDC, The Ohio State University Research Bulletin 1169, Southern Cooperative Series Research Bulletin 300. February 1985.

Harrington, David, Gerald Schluter and Patrick 0'Brien. "Agriculture's Links to the National Economy, Income and Employment," Agricultural Information Bull. No.504. USDA-ERS, October 1986.

Hill, Lowell D., Mack N. Leath, and Stephen W. Fuller. "Corn Movements in the United States: Interregional Flow Patterns and Transportation Requirements in 1977," North Central Regional Research Bulletin No. 275, Southern Cooperative Series Bulletin No. 253, Illinois Bulletin No.768, Agricultural Experiment Station, College of Agriculture, University of Illinois at Urbana-Champaign.

Hoffman, Linwood, Lowell Hill, and Mack N. Leath. "A Flexible Rail Rate Policy; Impacts on U.S. Feed Grains," USDA-ERS Technical Bulletin No. 1701. Washington, D.C. 20250 April 1985.

Koo, Won W. "Tariffs and Transport Costs on U.S. Wheat Exports," North Central Journal of Agricultural Economics, 6(2), July 1984, pp. 99-107.

Lamphear, F.C. and Ron Konecny. ADOTMATR Resource Economics and Management Analysis, Lincoln, Nebraska, 1986 (Sof tware manual).

Leath, Mack N., Lowell D. Hill, and Stephen W. Fuller. "Oat Movements in the United States: Interregional Flow Patterns and Transportation Requirements in 1977," North Central Regional Research Bulletin No.276, Southern Regional Cooperative Series No. 254, Illinois Bulletin No. 769. Agricultural Experiment Station, College of Agriculture, University of Illinois at Urbana-Champaign.

Miller, Ronald E. and Peter D. Blair. Input-Output Analys is Foundations and Extensions. Prentice Hall, Inc. Englewood Cliffs, New Jersey, 1985 .

Pagoulatos, Emilio, Angelos Pagoulatos, and Robert Sorensen, "Impact of Agricultural Export Trade on a State's Econony," North Central Journal of Agricultural Economics. 4(2), July 1982, pp. 103-107.

Penn, J.B., Bruce McCarl, Lars Brink, and George D. Irwin. "Modeling and Simulation of the U.S. Economy With Alternative Energy Availabilities," American Journal of Agricultural Economics, November 1976, pp. 663-671. 
Pollack, Susan. "USDA Actions", National Food Review, NFR-38, USDAERS Fall, 1987.

Ritz, Philip M. Definitions and Conventions of the 1982 Input-Output Study, Bureau of Economic Analys is Staff Paper, U.S. Department of Commerce, Washington D. C., July 1980.

Smith, Thomas R., "Inter-Industry Impacts of Feed Grain Transportation and Export Policy Changes Upon the Cornbelt," Unpublished Ph.D. Dissertation, The Ohio State University, 1988.

U.S. Bureau of the Census, Statistical Abstract of the United States, Washington D.C. 1972-1986. 